\title{
Assessing and Teaching Adult Learners' Basic and Advanced 21st Century Digital Literacy Skills
}

David J. Rosen, Newsome Associates

The focus of the Technology Solutions for Adult Basic Skills Challenges column begins with common challenges facing adult basic skills practitioners, expressed, for example, in the LINCS Integrating Technology group for which I am the moderator, in other LINCS groups, in my national and state conference or webinar presentations, or privately in face-to-face discussions or by phone or email. Solutions to these problems, at least in part through the use of technology, include: hardware such as desktop and laptop computers, smartphones, electronic tablets, VR Goggles, and electronic whiteboards; and digital software applications such as websites, course management systems, learning management systems, databases, and apps for mobile devices. Each article begins with a challenge and examines one or more possible technology solutions.

In the technology solutions column of this special issue of Adult Literacy Education, that focuses on Broadening the Lens on Adult Literacy Education Outcomes, I want to challenge our field to expand our view of digital literacy. Of course, basic digital literacy skills must be included, but we have to look beyond to the digital skills and attitudes adults need in order to research their questions; judge the quality of information they have found; and to solve problems at home, work and in their community that require or can benefit from the use of digital skills, comfort, confidence and fluency. These define the digital literacy capacity adults need to solve new problems facing us in a changing society, including the new problems created by ever-changing technology itself.

As adult basic skills researcher, practitioner and administrator Dr. Jen Vanek put it in a January, 2017 PIAAC Commissioned paper, "Using the PIAAC Framework for Problem Solving in Technology-Rich Environments to Guide Instruction: An Introduction for Adult Educators." https://bit.ly/2tKVSgf

The increasing complexity and number of technology tools in our communities has altered the nature of work, schooling, and daily life. This, and the attendant increased complexity in tasks and problem solving, positions learners (as well as teachers!) as life-long learners. To truly prepare learners to succeed outside the classroom, we need to teach more than academic content. Our instruction must also help learners develop the resilience they need to address future changes. By building a learner's ability to employ the problem-solving process, we can support their continued learning in a dynamic world. 


\section{Description of the Challenge}

Basic and advanced digital literacy and problem-solving skills are needed for success in postsecondary education, career pathways, work, and daily living and learning throughout our lives, but how can adult basic skills (including ESOL/ESL) programs and schools assess and teach these skills?

Basic and advanced adult basic and more advanced digital literacy skills are primarily defined by these three different sets of standards:

1. The Northstar Digital Literacy Assessment Standards for Essential Computer Skills (basic digital literacy skills) https://assets. digitalliteracyassessment.org/static/main_ website/docs/NDLA-standards-2018-11-18.pdf

\section{International Standards for Technology} Education (ISTE) Standards for Students https://www.iste.org/standards/for-students that include these seven more advanced digital literacy areas: Empowered Learner, Digital Citizen, Knowledge Constructor, Innovative Designer, Computational Thinker, Creative Communicator, and Global Collaborator. Although designed primarily for K-12 learners, these are increasingly also used in adult basic skills education especially for more advanced digital literacy skills.

\section{PIAAC PSTRE Conceptual Framework}

https://read.oecd-ilibrary.org/education/ piaac-problem-solving-in-technologyrich-environments-a-conceptualframework_220262483674\#page20 and Using the "PIAAC Framework for Problem Solving in Technology-Rich Environments to Guide Instruction: An Introduction for Adult Educators." https://bit.ly/2tKVSgf

\section{Possible Solutions}

For assessing basic digital literacy skills, these assessment tools for adult basic skills learners may be of interest:

1. Northstar Digital Literacy Assessment https://www.digitalliteracyassessment.org/ This includes free individual and subscriptionbased testing program versions. The subscription version offers an aligned online digital literacy curriculum, assessment training and the ability to award those who pass the assessment modules a certificate. Both versions are free to learners taking the assessments.

2. Total TekAssess This is a proprietary computer and Microsoft Office skills assessment. https://www.teknimedia.com/ html/digital-skills-assessment.html

\section{Microsoft digital literacy assessment} (free) https://www.microsoft.com/en-us/ digitalliteracy/assessment/instructions. aspx?lang=eng\&aid $=$ as $26 \mathrm{~b}$

\section{For assessing more advanced digital literacy} skills:

1. One possible resource for measuring student progress is the PIAAC-based PSTRE assessment Education and Skills Online (ESO). https://staticl.squarespace. com/static/51bb74b8e4b0139570ddf020/t/5 2276bd2e4b0ae4ae05ae899/1378315218944/ Education+and+Skills+Online.pdf

2. Another more advanced digital literacy assessment may be the Learning.com digital literacy assessments that received the ISTE Seal of Alignment for Readiness (see below for more information on the Seals of Alignment.) “Learning.com's two Digital Literacy 
Assessment resources are designed to assess student skills across all ISTE Standards for Students at the fifth and eighth grade levels. The assessments are accessed and completed online using a customized testing interface on the Learning.com website, and each assessment is created at a level appropriate for the target audience. The assessments use technology-enhanced questions that meet Web Content Accessibility Guidelines and are responsive for use across devices. Practice tests, real-time data and teacher resources are also integrated into this resource."

Seal of Alignment Review "The Learning. com Digital Literacy Assessments successfully underwent the International Society for Technology in Education (ISTE) Seal of Alignment review for Readiness. Reviewers determined this resource helps build foundational technology skills needed to support the ISTE Standards for Students." https://www.iste.org/standards/seal-ofalignment/digital-literacy-assessment

\section{For providing digital literacy instruction:}

1. The Northstar Digital Literacy Assessment subscription option provides access to a basic level adult digital literacy curriculum aligned to the Northstar Digital Literacy assessment https://www.digitalliteracyassessment.org/ news/2019/09/curricula-release-and-otherupdates. Note that a free selection of curated web-based learning resources is available at https://www.digitalliteracyassessment.org/ external-resources These resources were not created by Northstar, but have been carefully selected by their staff for alignment to the Northstar assessment.

2. Three resources that align with the ISTE standards and have received the ISTE seals of alignment (https://www.iste.org/standards/ seal-of-alignment) include:
a. Google/Applied Digital Skills https:// www.iste.org/standards/seal-of-alignment/ google-applied-digital-skills and https:// applieddigitalskills.withgoogle.com/s/en/ home

b. 21 things (for teachers) https://id.iste.org/ docs/soa/21things4teachers-findingsreportfinal.pdf?sfvrsn=2 and http:// www.21things4teachers.net/21-Things/ index.html

\section{c. Teq Online Professional development} integrating technology courses (now called OTIS) https://id.iste.org/docs/ soa/findingsreportiste-teqopd_final. pdf?sfvrsn=2 and https://otis.teq.com/ courses/category/id/20/events/BlendedLearning

\section{Reflections}

There are no ideal solutions, at least not yet, for assessing and teaching advanced adult digital literacy skills. However, there may be some significant potential in the years ahead as technology problem-solving simulations are developed, perhaps made more robust with artificial intelligence and virtual reality applications, and as new formative and summative assessments are developed for the more complicated and contextualized problem-solving tasks that benefit from the use of digital technology. 